\title{
3. Good global governance through trade: constitutional moorings
}

\section{Joris Larik}

\section{INTRODUCTION}

Ensuring good global governance through trade is not just a powerful idea, ${ }^{1}$ or a global 'strategy'; ${ }^{2}$ it is also firmly anchored in the highest laws of the European Union (EU or Union) - its 'constitutional charter'. ${ }^{3}$ According to the Treaty on European Union (TEU), ${ }^{4}$ the EU is to 'promote an international system based on stronger multilateral cooperation and good global governance' (Article 21(2)(h)) and 'uphold and promote its values and interests' (Article 3(5)) in its external relations. One crucial means to these lofty ends is the EU's Common Commercial Policy (CCP). This policy is concerned a priori with the pursuit of goals at the heart of international trade, such as 'free and fair trade' (Article 3(5) TEU) and 'the harmonious development of world trade, the progressive abolition of restrictions on international trade and on foreign direct investment' (Article 206 Treaty on the Functioning of

1 See Chapters 1 and 2, this volume.

2 European Commission, 'Global Europe: Competing in the World: A Contribution to the EU's Growth and Jobs Strategy', COM(2006) 567 final, Brussels, 4 October 2006, 2: 'Through our trade policies, we also seek to contribute to a range of the Union's external goals, in particular development and neighbourhood objectives.'

3 Case 294/83 Parti écologiste 'Les Verts' [1986] ECR 1339, para 23.

4 Throughout this chapter 'TEU' and 'TFEU' refer to the consolidated versions of the Treaty on European Union and the Treaty on the Functioning of the European Union [2012] OJ C 326/1. The consolidated text of the TEU post-Nice, but pre-Lisbon (Treaty on European Union (consolidated text) [2002] OJ C 325/5) is referred to 'TEU (Nice version)'. Unless otherwise indicated, 'TEC' refers to the Treaty establishing the European Community in the consolidated version following the Nice revision, i.e. the Treaty establishing the European Community (consolidated text) [2002] OJ C 325/33. 
the European Union (TFEU); see also Article 21(2)(e) TEU). However, as a textual innovation through the Lisbon Treaty reform, the CCP is henceforth to 'be conducted in the context of the principles and objectives of the Union's external action' (Article 207(1) TFEU). Among these, we find now a plethora of foreign policy objectives - a "wish list for a better world', 5 if you will - which can be placed under the general conceptual umbrella of 'good global governance'.6 'Global governance' can be defined as 'the management of global problems and the pursuit of global objectives through concerted efforts of states and other international actors'.7 'Good', as an overtly normative statement, is to be interpreted then as a vision of global governance informed by the pursuit of global objectives according to the values and principles set out in the EU Treaties. The latter reflects a constitutionally entrenched 'sanguine world view', ${ }^{8}$ representing the external dimension of what can be called the 'the conscience of the Constitution'.9

Promoting 'good global governance' through trade policy brings together two of the hallmarks of the EU as an international actor. On the one hand, it concerns the area of the EU's most obvious asset, its economic clout. Despite tectonic shifts at work in the distribution of global economic power, the EU, for the foreseeable future, stands its ground as one of the world's foremost trade powers, being 'the world's largest economy', 'the world's largest trading block [sic]' and 'the world's second-largest investor' ${ }^{10}$ On the other hand, the EU is not only

5 Wiebke Drescher, 'Ziele und Zuständigkeiten', in Andreas Marchetti and Claire Demesmay (eds), Der Vertrag von Lissabon: Analyse und Bewertung (Nomos 2010) 59-71, 68 (in the original: 'Wunschzettel für eine bessere Welt').

6 Eleftheria Neframi, 'Vertical Division of Competences and the Objectives of the European Union's External' in Marise Cremona and Anne Thies (eds), The European Court of Justice and External Relations: Constitutional Challenges (Hart 2014), 73-94, 73.

7 Martin Ortega, 'Building the Future: The EU's Contribution to Global Governance', EUISS Chaillot Paper No. 100, April 2007, 46 (italics omitted).

8 Joris Larik, 'Entrenching Global Governance: The EU's Constitutional Objectives caught between a Sanguine World View and a Daunting Reality', in Bart Van Vooren, Steven Blockmans and Jan Wouters (eds), The EU's Role in Global Governance: The Legal Dimension (Oxford University Press 2013) 7-22.

9 To borrow an expression used in Indian constitutional law: Granville Austin, The Indian Constitution: Cornerstone of a Nation (Clarendon 1966) 50.

10 European Commission, Directorate-General for Trade, European Union Trade and Investment 2014 (Publications Office of the European Union 2014); see also Marise Cremona, 'The External Dimension of the Internal Market', in 
a 'formidable power in trade' but also 'a power through trade' ${ }^{11}$ In other words, trade power 'can be used to attain other, non-economic objectives'. ${ }^{12}$ This relates to the idea of the EU not only as a 'civilian power', ${ }^{13}$ but indeed as a 'normative power' 14 which shapes the world around it by harnessing its economic strength according to a larger vision and based on values which go beyond the strictly economic realm.

In order to capture the constitutional moorings of the mandate to pursue 'good global governance' through trade and to elucidate its implications, the present chapter shines the spotlights on this issue through three different lenses: historical, comparative and legalinstitutional. First, it retraces the evolution of this idea and its progressive codification in the course of time. Second, it puts the EU's constitutional 'conscience' as a trade power into a comparative context. Against this double backdrop, the chapter then turns to the legal significance of such norms, addressing what they can - and cannot - achieve as norms of EU constitutional law.

\section{THE EU'S EVOLVING CONSTITUTIONAL CONSCIENCE}

The EU did not grow a 'constitutional conscience' with regard to the exercise of its trade power overnight. Just as national constitutions are 'more deeply rooted in a nation's history and culture' and more 'political

Catherine Barnard and Joanne Scott (eds), The Law of the Single European Market (Hart 2002) 351-94.

11 Sophie Meunier and Kalypso Nicolaïdis, 'The European Union as a Trade Power', in Christopher Hill and Michael Smith (eds), International Relations and the European Union (2nd edn, Oxford University Press 2011) 275-98, 294 (emphasis in the original).

12 Marise Cremona, 'The Union's External Action: Constitutional Perspectives', in Giuliano Amato, Hervé Bribosia and Bruno de Witte (eds), Genesis and Destiny of the European Constitution (Bruylant 2007) 1173-217, 1213; also Angelos Dimopoulos, 'The Effects of the Lisbon Treaty on the Principles and Objectives of the Common Commercial Policy' (2010) 15(2) European Foreign Affairs Review 153, 153.

13 François Duchêne, 'Europe's Role in World Peace', in Richard Mayne (ed.), Europe Tomorrow: Sixteen Europeans Look Ahead (Fontana 1972) 32-47.

14 Ian Manners, 'Normative Power Europe: A Contradiction in Terms?' (2002) 40(2) Journal of Common Market Studies 235, 245 (referring to trade policy as norm diffusion through 'transference'). See also Bartels (Chapter 4, this volume) for an account of the EU's treaty-making practice in this respect. 
in nature' than other sources of law, ${ }^{15}$ EU constitutional law, as it stands today, has absorbed and entrenched policy priorities and, more generally, a world outlook shaped by the founders of the European project and six decades of integration history. This becomes evident when retracing the linkages of trade policy with a wider foreign policy agenda in the Treaties over the course of time. The various norms on which this chapter focuses are the result of an evolution which commenced with the inception of European integration itself, and which received a new impetus with the Convention on the Future of Europe of 2002-03. The results of the latter eventually spilled over into the Lisbon Treaty, and thus into the primary law in force today.

\subsection{From the Communities to the Union}

The Treaty establishing the European Coal and Steel Community (ECSC) of 1951 already reveals a 'bigger picture' into which economic integration could be situated. It states in its preamble 'that world peace can be safeguarded only by creative efforts commensurate with the dangers that threaten it'. ${ }^{16}$ The operative part includes objectives pertaining to international trade as a corollary of the common market. The ECSC is mandated to 'see that the common market [for coal and steel] is regularly supplied, taking account of the needs of third countries' 17 and to 'further the development of international trade and see that equitable limits are observed in prices charged on external markets'. ${ }^{18}$ However, 'grand vision' and trade objectives are not yet explicitly linked to each other.

The Treaty establishing the European Economic Community (EEC Treaty), in its original 1957 version, expresses the desire of the contracting parties to contribute 'to the progressive abolition of restrictions on international trade' 19 by virtue of a Common Commercial Policy. While the 'task' of the EEC is centred on the Common Market, ${ }^{20}$ the 'activities' of the Community include 'the establishment of a common customs tariff

15 Monica Claes and Maartje de Visser, 'Reflections on Comparative Method in European Constitutional Law', in Maurice Adams and Jacco Bomhoff (eds), Practice and Theory in Comparative Law (Cambridge University Press 2012) 143-69, 157.

16 First recital of the preamble, Treaty establishing the European Coal and Steel Community (ECSC Treaty), Paris, signed 18 April 1951 (emphasis added).

17 Art 3(a) ECSC Treaty.

18 Art 3(f) ECSC Treaty.

19 Sixth recital of the preamble, Treaty establishing the European Economic Community (EEC Treaty), Rome, signed 25 March 1957.

20 Art 2 EEC Treaty. 
and of a common commercial policy toward third countries' 21 as well as 'the association of overseas countries and territories in order to increase trade and to promote jointly economic and social development'. ${ }^{22}$ The CCP is furthermore given specific objectives: 'the harmonious development of world trade' and the 'progressive abolition of restriction on international trade and the lowering of customs barriers'. ${ }^{23}$ From these various provisions, it becomes apparent that both the internal (intraCommunity) and external economic spheres are conceived of as intertwined and, furthermore, that trade policy is not to be conducted in clinical isolation from other policies, such as development cooperation.

In the following decades, as European integration progressed, the scope of activities of the Communities and later of the Union widened, including those pertaining to what is now called 'good global governance'. Through the Single European Act (SEA) of 1986, European Political Cooperation in the area of 'foreign policy' acquired a treaty basis. ${ }^{24}$ The SEA also extended the policies of the EEC to other fields with an external dimension, including environmental protection. ${ }^{25}$

The Treaty on European Union of 1993 introduced the rather complex pillar structure. ${ }^{26}$ The newly established Union included the Communities as one of the three pillars next to the inter-governmental Common Foreign and Security Policy (CFSP) and Justice and Home Affairs (JHA), which was later narrowed down to Police and Judicial Cooperation in Criminal Matters. The emergence of the CFSP is a watershed in EU external relations law as it legally codifies and institutionalizes European cooperation in this area.

The original Maastricht TEU included the objective for the Union 'to assert its identity on the international scene'. ${ }^{27}$ What this international identity would consist of more specifically, however, was left open. Nevertheless, Maastricht and the subsequent reforms at Amsterdam and

\footnotetext{
21 Art 3(b) EEC Treaty.

22 Art 3(k) EEC Treaty; see also Arts 131 and 132 EEC Treaty.

23 Art 110(1) EEC Treaty.

24 Art 1(3) Single European Act (SEA) [1987] OJ L 169/1. Note also the fifth recital of the preamble to the SEA, which refers to the principles of democracy, the rule of law and human rights, as well as to contributing to international peace and security in external relations.

25 Art 25 SEA, introducing then Art 130r TEC (subsequently Art 174 TEC).

26 See Marise Cremona, 'The Common Foreign and Security Policy of the European Union and the External Relations Powers of the European Community', in David O'Keeffe and Patrick Twomey (eds), Legal Issues of the Maastricht Treaty (Wiley Chancery 1994) 247-58.

27 Art 2 TEU (Nice version).
} 
Nice added a number of provisions, both in the TEU and the amended TEC, from which the basic features of such an identity could be gleaned. These include the codification of 'values' on which the Union was founded, ${ }^{28}$ the general objectives of the Union according to Article 2 TEU (Nice version) and the specific objectives of each policy area to the extent that these had an external dimension. The latter consisted of the CFSP, which had its own set of goals spelled out in the TEU, ${ }^{29}$ and the external policies of the Community, which now also comprised, next to the traditional CCP, development cooperation, ${ }^{30}$ and economic, financial and technical assistance to third countries. ${ }^{31}$

The list of activities of the European Community (with the adjective 'Economic' having been omitted from its name) was extended to include development cooperation. ${ }^{32}$ This policy area was endowed with its own set of specific objectives, which were to foster:

- the sustainable economic and social development of the developing countries, and more particularly the most disadvantaged among them;

- the smooth and gradual integration of the developing countries into the world economy; and

- the campaign against poverty in the developing countries. ${ }^{33}$

Moreover, Community development policy was to 'contribute to the general objective of developing and consolidating democracy and the rule of law, and to that of respecting human rights and fundamental freedoms'. ${ }^{34}$ Crucially for good global governance through trade, the amended TEC also obliged the Community to 'take account of the objectives referred to in Article 177 [on development cooperation] in the policies that it implements which are likely to affect developing countries', ${ }^{35}$ which include trade policy as well as internal policies such as the Common Agricultural Policy and the Internal Market.

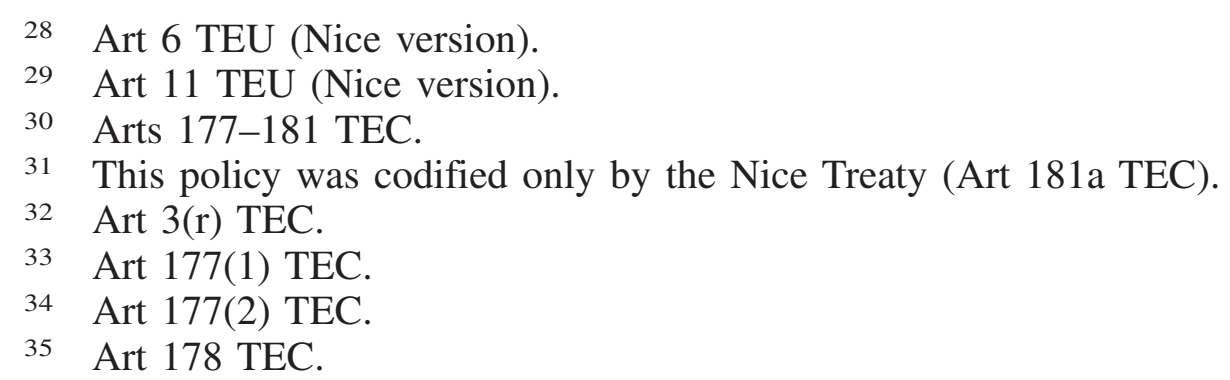




\subsection{The Convention on the Future of Europe}

Shortly after the Nice Treaty and with the enlargement of the Union to the east and south looming, another major recasting of the basic structure of the EU was launched. This marks the beginning of a decade-long treaty reform process culminating in the Lisbon Treaty. ${ }^{36}$ However, the main conceptual work, also and especially with regard to the codification of the EU's foreign policy agenda and the orientation of trade policy, was done at the Convention on the Future of Europe of 2002-03.

Kicking off the reform process, the Laeken Declaration of 2001 publicly asked whether 'Europe [does] not, now that is finally unified, have a leading role to play in a new world order, that of a power able both to play a stabilising role worldwide and to point the way ahead for many countries and peoples'. ${ }^{37}$ In providing the answer itself, the Declaration stated that 'Europe needs to shoulder its responsibilities in the governance of globalisation' ${ }^{38}$ In doing so, the EU was to become 'a power wanting to change the course of world affairs in such a way as to benefit not just the rich countries but also the poorest' and a 'power seeking to set globalisation within a moral framework'. 39

The Laeken Declaration represents another leap in terms of global ambition for the EU, now linking comprehensive international engagement with overt normativity and an 'active paradigm' ${ }^{40}$ which eventually found its way into the primary law by virtue of the Lisbon Treaty.

The Convention on the Future of Europe started its work in February 2002 and concluded in July 2003 by presenting to the European Council

36 See, for instance, Paul Berman, 'From Laeken to Lisbon: The Origins and Negotiation of the Lisbon Treaty', in Andrea Biondi, Piet Eeckhout and Stephanie Ripley (eds), EU Law after Lisbon (Oxford University Press 2012) 3-39; Paul Craig, The Lisbon Treaty: Law Politics and Treaty Reform (Oxford University Press 2010) 1-31; Jean-Claude Piris, The Lisbon Treaty: A Legal and Political Analysis (Cambridge University Press 2010) 7-63.

37 Presidency Conclusions, European Council meeting, Laeken, 14-15 December 2001, Annex I, Laeken Declaration on the Future of the European Union, 20.

38 Ibid.

39 Ibid.

40 Fabian Amtenbrink and Dimitry Kochenov, 'The Active Paradigm of the Study of the EU's Place in the World: An Introduction', in Fabian Amtenbrink and Dimitry Kochenov (eds), The European Union's Shaping of the International Legal Order (Cambridge University Press 2013) 1-18. 
a Draft Treaty establishing a Constitution for Europe. ${ }^{41}$ During the general debate at the Convention on external action in July 2002, '[m]any stressed that the values which were at the heart of the Union were themselves an argument for a greater role globally, and that these values should underpin and inform the Union's external policies'. ${ }^{42}$ Subsequently, the idea to formulate - and constitutionally codify - a comprehensive normative foreign policy agenda that would guide the Union's external action, including trade policy, was born at the Convention.

The Præsidium of the Convention drafted what would later become Article 3 TEU on the general objectives of the Union, which included a paragraph on relations with the rest of the world. After a first draft had been circulated in February 2003, ${ }^{43}$ several amendments called for the inclusion of 'free and fair trade' as a goal, ${ }^{44}$ which was taken up by the Convention in its final draft. ${ }^{45}$ The Working Group on External Action also perceived 'the need to define more clearly in a future Treaty the underlying objectives of EU external action' ${ }^{46}$ According to the Convention Secretariat, 'Working Group VII [on External Action] opted for the approach of defining the principles and objectives of all external action in a single Article, therefore deleting the lists of specific objectives of each policy area concerned in existing Articles'. ${ }^{47}$

41 For a detailed account see Peter Norman, The Accidental Constitution: The Story of the European Convention (2nd edn, EuroComment 2005).

42 Secretariat of the European Convention, Summary Report of the Plenary Session - Brussels, 11 and 12 July 2002, Brussels, 16 July 2002, CONV 200/02, 3 .

43 Secretariat of the European Convention, Draft of Articles 1 to 16 of the Constitutional Treaty, Brussels, 6 February 2003, CONV 528/03, Annex I: Draft Text of the Articles of the Treaty Establishing a Constitution for Europe, 3.

44 See Secretariat of the European Convention, Suggestion for Amendment by the Earl of Stockton MEP, http://european-convention.europa.eu/docs/Treaty/ pdf/3/Art\%203a\%20Stockton.pdf (accessed 22 June 2015) (proposing to add 'the promotion of free and fair trade in the wider world' to the article on Union objectives); and Secretariat of the European Convention, Suggestion for Amendment by Elmar Brok and others, http://european-convention.europa.eu/docs/ Treaty/pdf/3/Art\%203\%20EPP.pdf (accessed 22 June 2015) (proposing to add 'free trade', but sans 'fair').

45 Art 3(4) Draft Treaty establishing a Constitution for Europe, Brussels, 18 July 2003, CONV 850/03.

46 Secretariat of the European Convention, Working Group VII on External Action, Summary of the Meeting held on 8 October 2002, Brussels, 11 October 2002, CONV 342/02, 6 (emphasis added).

47 Secretariat of the European Convention, Draft Articles on External Action in the Constitutional Treaty, 23 April 2003, CONV 685/03, 25. 
This would have constituted a major shift in the way in which Union policies had been organized in the Treaties. However, this streamlining exercise succeeded only in part. On the one hand, the draft text submitted by the working group to the Convention on EU external action had indeed omitted the individual objectives for the CFSP, development cooperation and economic, financial and technical aid. On the other hand, the CCP had retained objectives of its own and the newly inserted section on humanitarian aid even included new policy-specific goals. With regard to trade policy in particular, the text proposed by Working Group VII and endorsed by the Præsidium reproduced most of the language of former Articles 131 and 133(1) TEC, but added references to foreign direct investment as well as - importantly for the explicit linkage of trade and 'good global governance' - to the general principles and objectives of external action (that is, to what is now Article 21 TEU). ${ }^{48}$

It was also during the work of the working group on external action that the reference 'to promote an international system based on stronger multilateral cooperation and good global governance' 49 was added to what would later become Article 21 TEU. There were, furthermore, calls to include explicit references to contribute to the preservation and promotion of 'global public goods' ${ }^{50}$ These were not successful, and the concept of a 'global public good' thus remains absent from the EU Treaties. Nonetheless, even if not labelled this way, many of the ideas enshrined in Articles 3(5) and 21 TEU undoubtedly fit the usual definition of 'global public goods'. ${ }^{51}$

48 Ibid 52-4.

49 Secretariat of the European Convention, Working Group VII on External Action, Final Report of Working Group VII on External Action, Brussels, 16 December 2002, CONV 459/02, 3.

50 For example, Secretariat of the European Convention, Suggestion for Amendment by $\mathrm{Mr}$ Voggenhuber and others, http://european-convention. europa.eu/docs/Treaty/pdf/861/Art\%20III\%20188\%20Voggenhuber\%20EN.pdf (accessed 22 June 2015); Secretariat of the European Convention, Suggestion for Amendment by Mr Brok and others, http://european-convention.europa.eu/docs/ Treaty/pdf/861/Art1Brok\%20EN.pdf (accessed 22 June 2015); and Secretariat of the European Convention, Suggestion for Amendment by Mr Ingvar Svensonn, http://european-convention.europa.eu/docs/Treaty/pdf/861/Art1Svensson\%20EN.pdf (accessed 22 June 2015), who names as examples in the explanatory note 'biodiversity, preservation of the atmosphere, access to fresh water, and effective prevention of HIV/AIDS'.

51 Cf. Daniel Bodansky, 'What's in a Concept? Global Public Goods, International Law, and Legitimacy' (2012) 23(3) European Journal of International Law 651, 652-4. 
The text agreed by the Convention and transmitted to the President of the European Council, ${ }^{52}$ compared with the situation of the Nice Treaty and what preceded it, certainly shows progress in terms of codifying the foreign policy agenda of the EU. ${ }^{53}$ However, by using former Article 11 TEU (Nice version) on CFSP objectives as the template for the general article on EU external action (now Article 21 TEU), and without replacing it in the section on the CFSP, the latter policy is deprived of its own set of specific objectives, as is the section on economic, financial and technical aid. In contrast, the external policies not only on trade, but also on development and the newly codified section on humanitarian aid, all received a set of policy-specific objectives. A distinction thus remains between the overall objectives of EU external action - its contribution to 'good global governance' - and the specific goals of its trade policy.

\subsection{The Lisbon Treaty}

The Treaty establishing a Constitution for Europe was signed by the Member States in Rome in October 2004. However, after the failed referendums in France and the Netherlands in 2005, a subsequent 'period of reflection' led to the drafting of a 'reform treaty' that would not replace the existing treaties but would amend them. ${ }^{54}$ The 'constitutional concept', pushed by the Convention, was officially dropped by the Council. ${ }^{55}$ However, this should not be confused with depriving the legal order of the Union of its constitutional features. ${ }^{56}$ The resulting Lisbon

\footnotetext{
52 Draft Treaty establishing a Constitution for Europe, Brussels, 18 July 2003, CONV 850/03.

53 See Marise Cremona, 'The Draft Constitutional Treaty: External Relations and External Action' (2003) 40 Common Market Law Review 1347, 1348-9.

54 Treaty of Lisbon amending the Treaty on European Union and the Treaty establishing the European Community, signed at Lisbon, 13 December 2007 (Lisbon Treaty) [2007] OJ C 306/1. See further Gráinne de Búrca, 'The EU on the Road from the Constitutional Treaty to the Lisbon Treaty' (2008) Jean Monnet Working Paper 03/08.

55 Presidency Conclusions of the Brussels European Council, 21 and 22 June 2007, 20 July 2007, 11177/1/07 REV 1, Annex I: IGC Mandate, 15.

56 See, in particular, Stefan Griller, 'Is this a Constitution? Remarks on a Contested Concept', in Stefan Griller and Jacques Ziller (eds), The Lisbon Treaty: EU Constitutionalism without a Constitutional Treaty? (Springer 2008) 21-56 (arguing in favour of the constitutional credentials of the EU after Lisbon).
} 
Treaty, after going through some ratification troubles of its own, entered into force on 1 December 2009.57

The Lisbon Treaty incorporated virtually all of the reforms proposed by the Constitutional Treaty, leaving aside mostly symbolic provisions such as those on the flag, the anthem, the motto and the term 'Union Foreign Minister' ${ }^{58}$ The reformed codified foreign policy agenda of the EU had not been abandoned or rolled back in the Lisbon Treaty. In terms of the basic structure - which, under Lisbon, comprises two treaties (the TEU and TFEU) - a relocation of the articles on the general objectives of EU external action took place. In the Constitutional Treaty, one article introduced a comprehensive part on EU 'External Action' containing all the external policies of the Union. Under the Lisbon Treaty, by contrast, this article (Article 21 TEU) was situated in the TEU at the start of its Title V on 'General Provisions on the Union's External Action and Specific Provisions on the Common Foreign and Security Policy'. This title contains merely the external policy area of the CFSP/CSDP, while the others, including trade policy, are now to be found in Part $\mathrm{V}$ of the TFEU on 'External Action by the Union'. Nonetheless, Article 205 TFEU, which introduces Part V, refers back to Article 21 TEU.

In the primary law now in force, the idea of ensuring good governance through trade has become a constitutional mandate for the EU. On the one hand, the Union is to continue to pursue goals intimately connected with trade (that is, to promote 'free and fair trade') $)^{59}$ and 'contribute, in the common interest, to the harmonious development of world trade, the progressive abolition of restrictions on international trade and on foreign direct investment, and the lowering of customs and other barriers' ${ }^{60}$ On the other hand - and this is the novelty post-Lisbon ${ }^{61}$ - its trade policy 'shall be conducted in the context of the principles and objectives of the Union's external action' at large (that is, all the objectives listed in Articles 3(5) and 21 TEU). These include the promotion of the Union's values and interests, and contributing also to peace, democracy, the rule of law, security, sustainable development, eradication of poverty, human rights and respect for international law - a kaleidoscope of aspects of what the EU considers to be 'good global governance'.

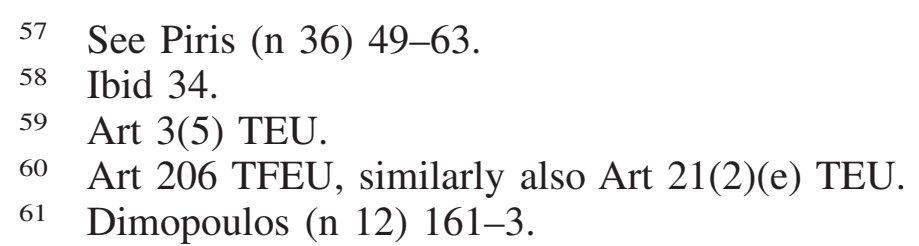




\section{TRADE AND GOOD GOVERNANCE: A COMPARATIVE PERSPECTIVE}

The EU now boasts in its primary law a very ambitious foreign policy agenda. With regard to trade policy, the Treaties also provide policyspecific goals but these are explicitly put under the umbrella of this wider agenda. Given the prominence of this agenda in the current primary law, it is worthwhile to survey other constitutions, in order to determine how 'special' the EU is in this respect. Are other trade powers endowed with such a 'constitutional conscience'? To this end, the following paragraphs will elaborate upon two points. First, in general, many contemporary constitutions address 'global governance' at least in abstract terms, for instance, through calls for a more 'just' world order. Second, it seems to be rather rare for a constitution to address specifically trade policy and its goals, much less to link it to a wider constitutionally entrenched foreign policy agenda. Hence, the latter remains a speciality of the EU.

\section{1 'Good Global Governance’: Constitutional Acknowledgements}

They are part of a wider trend in constitutional design, which earlier I termed 'dynamic internationalization' 62 - the progressive codification of foreign policy goals, in many cases with idealistic underpinnings.For instance, the German Basic Law acknowledges, in a clearly universalist tone, 'inviolable and inalienable human rights as the foundation of every community, of peace and justice in the world'. ${ }^{63}$ The Portuguese Constitution, furthermore, stresses that Portugal's international relations will be governed, inter alia, by the overarching objectives of 'the emancipation and progress of humanity' 64 and 'the creation of an international order capable of safeguarding peace and justice in relations between peoples' ${ }^{65}$ The Bulgarian Constitution, in a similar vein, makes 'the promotion of a just international order' 66 an objective of the state.

62 Joris Larik, 'Shaping the International Order as an EU Objective', in Fabian Amtenbrink and Dimitry Kochenov (eds), The European Union's Shaping of the International Legal Order (Cambridge University Press 2013) 62-87, 64.

63 Art 1(2), German Constitution.

64 Art 7(1), Portuguese Constitution; on Portuguese constitutional foreign policy objectives in this provision see Paulo Jorge Canelas de Castro, 'Portugal's World Outlook in the Constitution of 1976' (1995) 71 Boletim da Faculdade de Direito da Universidade de Coimbra 489.

65 Art 7(2), Portuguese Constitution.

66 Art 24(2), Bulgarian Constitution. 
Beyond Europe, similar constitutional language can be found. The preamble to the Constitution of the People's Republic of China, today undeniably one of the world's leading economic and trade powers, ${ }^{67}$ contains a number of guidelines for its foreign policy. It stresses that

China adheres to an independent foreign policy as well as to the five principles of mutual respect for sovereignty and territorial integrity, mutual non-aggression, non-interference in each other's internal affairs, equality and mutual benefit, and peaceful coexistence in developing diplomatic relations and economic and cultural exchanges with other countries; China consistently opposes imperialism, hegemonism and colonialism, works to strengthen unity with the people of other countries, supports the oppressed nations and the developing countries in their just struggle to win and preserve national independence and develop their national economies, and strives to safeguard world peace and promote the cause of human progress. ${ }^{68}$

This language can be seen as less proactive in exporting and promoting normative standards around the world. ${ }^{69}$ Nonetheless, the preamble does exhibit the parameters of what China would consider not to be 'good global governance' - for instance, interference and imperialism.

The Japanese Constitution, too, exhibits references concerning the 'global common good'. It expresses the determination 'to preserve [Japan's] security and existence, trusting in the justice and faith of the peace-loving peoples of the world' as well as the belief 'that no nation is responsible to itself alone, but that laws of political morality are universal'. ${ }^{70}$ The Constitution of Brazil, moreover, enumerates 'fundamental principles' governing the country's foreign policy; next to 'national independence' these include 'cooperation among people for the progress of humanity'.71, while certainly verbose, from a comparative point of view the EU Treaties are by no means unique in expressing a desire for their constitutional organs to contribute to 'good global governance' or similar notions such as 'a just international order'.

67 Hanns Günther Hilpert, China's Trade Policy: Dominance without the Will to Lead, SWP Research Paper No. 1, January 2014, 7-10.

68 Preamble, Constitution of the People's Republic of China.

69 The 'five principles' originate from a treaty between China and India in 1954 and have since been the cornerstones of Chinese foreign policy: see Anu Bradford and Eric Posner, 'Universal Exceptionalism in International Law' (2011) 52 Harvard International Law Journal 3, 26.

70 Preamble, Japanese Constitution.

71 Art 4, Brazilian Constitution. 


\subsection{Good Governance through Trade: an EU Speciality}

Regardless of more general references that fit the theme of 'good global governance', only a few constitutions address trade policy in terms of its substantive goals. ${ }^{72}$ The presence of specific trade goals can be explained through the particular historical trajectory of the EU, as outlined in the previous section, which started out with an emphasis on economic integration and the corresponding formulation of a common trade policy. However, linking trade policy with a wider normative agenda is a distinctive feature of the EU - one which cannot be explained by its original nature as a functional international organization.

A notable exception to this general rule is the Swiss Constitution, which is similar to the EU Treaties, albeit to a limited degree. Next to general references in the realm of 'good global governance' - such as its commitment 'to an enduring conservation of the natural resources and to a peaceful and just international order' ${ }^{73}$ to 'the alleviation of need and poverty in the world, and to the respect for human rights [...]'74 - the Swiss Constitution contains an article devoted specifically to 'foreign trade', which reads:

1. The Confederation safeguards the interests of the Swiss economy abroad.

2. In special cases, it may take measures to protect the domestic economy. It may, if necessary, depart from the principle of economic freedom. ${ }^{75}$

On the one hand, this is similar to the EU Treaties in that both a constitutional call for 'good global governance' and an external trade policy geared towards certain ends are present in Swiss constitutional law. On the other hand, what is missing is a clear link between the two elements - that is, an instruction to use trade policy for the benefit of the wider normative agenda. In the Swiss case, the constitutional mandate, as

72 Foreign trade is sometimes made a federal competence in federal systems (e.g. Art 8(3), United States constitution). This is then simply a matter of allocating power between different levels of government, rather than of guiding trade policy towards certain normative ends.

73 Art 2(4), Swiss Constitution.

74 Art 54(2), Swiss Constitution.

75 Art 101, Swiss Constitution. On the proliferation of 'programmatic' norms in general in Swiss constitutional law see Ulrich Häferlin, Walter Haller and Helen Keller, Schweizerisches Bundesstaatsrecht (8th edn, Schulthess 2012) 57. 
far as foreign policy is concerned, is 'good global governance' and an economically oriented, assertive trade policy, rather than 'good global governance' through trade policy in the fashion of the EU Treaties.

\section{LEGAL SIGNIFICANCE: MANDATE, INSTITUTIONS AND IMPLEMENTATION}

As the previous sections have demonstrated, the idea of promoting good global governance through trade as a constitutional mandate for the EU has grown over decades and is now firmly established in the primary law. Such a constitutional mandate, moreover, is rather rare from a comparative perspective. While many constitutions today give a nod to 'good global governance' at large, making the explicit connection between trade policy and global governance is a speciality of the EU. In this section, the legal significance of such constitutional provisions will be analysed. What force do they have as legal norms, what do they entail for the institutions called upon in the Treaties to pursue this normative agenda through the CCP, and how are they being implemented? To shed light on these aspects of the constitutional moorings of 'good global governance through trade' in the EU, the following paragraphs will address first the general legal significance of such externally oriented constitutional objectives, followed by their role in the institutional architecture of the EU, and lastly an illustration of how they are implemented in EU legislation with a trade dimension.

\section{1 'Good Global Governance’ as a Constitutional Mandate}

As part of the EU Treaties - understood as the 'constitutional charter' 76 of the EU - the contents of Articles 3(5) and 21 TEU, as well as Articles 205-207(1) TFEU, are legally binding norms of primary law. Hence, based on the principle of primacy, they reign supreme over any secondary EU legislation as well as over the law of the Member States. ${ }^{77}$ Even if by

76 Parti écologiste 'Les Verts' (n 3); also Joined Cases C-402/05 P and C-415/05 P Kadi and Al Barakaat [2008] ECR I-6351, para 281. Further, Paul Craig, 'Constitutions, Constitutionalism, and the European Union' (2001) 7 European Law Journal 125 (arguing that the EU legal order exhibits 'thick' constitutional features); and Griller (n 56).

77 The principle of primacy does not feature in the EU Treaties, but see Declaration No. 17 concerning Primacy, attached to the Lisbon Treaty. Further, Piris (n 36) 79-82. 
certain commentators their content is ridiculed as 'redolent of motherhood and apple pie', ${ }^{78}$ their content and status are the result of the drafting and ratification process of the primary law as it stands today. In other words, to contribute to good global governance through trade is the stated and entrenched intention of the Union's constitutional legislator (pouvoir constituant). ${ }^{79}$

That being said, this constitutional mandate is not endowed with either a particularly strong obligatory or prohibitive force, at least in any immediate sense. In an early judgment, the Court of Justice of the European Union (CJEU) ruled that 'it will always be necessary to reconcile to a certain degree the various objectives of Article 3 [ECSC Treaty] since it is clearly impossible to attain them all fully and simultaneously as those objectives constitute general principles which must be observed and harmonized as far as possible' ${ }^{80}$

Even though the Court noted that the objectives enshrined in the Treaties have 'obligatory force', ${ }^{81}$ their 'normativity' 82 is thus rather limited in at least two ways. First, these provisions by no means establish individual rights: no individual may address the CJEU and claim that the Treaties were violated by adopting (or failing to adopt) a particular trade measure that does not sufficiently advance the cause of, for instance, promoting the rule of law or democracy. As the CJEU has ruled regarding the objectives of the former Community, these 'cannot have the effect either of imposing legal obligations on the Member States or of conferring rights on individuals' 83

Second, even aside from individual standing, failure to fully live up to constitutional objectives, especially those of such a broadly defined and ambitious nature, is in itself unlikely to amount to an infringement of the Treaties to be invoked by the EU institutions and Member States before the CJEU. Only in the most extreme cases of manifest disregard would this become arguable. Regarding the objectives of the CCP in particular,

78 Alan Dashwood and others, Wyatt \& Dashwood's European Union Law (6th edn, Hart 2011) 903, referring to Art 21 TEU.

79 Larik (n 8) 19-21.

80 Case 8/57 Groupement des hauts fourneaux et aciéries belges $v$ High Authority [1958] ECR English special edition 245, 253.

81 Case 6/72 Continental Can [1973] ECR 215, para 25.

82 On the normativité limitée of constitutional objectives in general, Pierre de Montalivet, Les objectifs de valeur constitutionnelle (Dalloz 2006) 563.

83 Case C-339/89 Alsthom Atlantique [1991] ECR 1991 I-107, para 9. Note also Case C-181/06 Deutsche Lufthansa [2007] ECR I-5903, para 31 (stating that the codified objectives and activities of the former Community 'do not lay down obligations on Member States or public or private bodies'). 
the Court made clear in the Dürbeck case that the "aim to contribute, in the common interest, to the harmonious development of world trade, the progressive abolition of restrictions on international trade [...]", cannot be interpreted as prohibiting the Community from enacting, upon pain of committing an infringement of the Treaty, any measure liable to affect trade'. ${ }^{84}$

This limited legal force also finds confirmation in the long-standing case law of the Court of Justice regarding the position of World Trade Organization law within the Union legal order, according to which both individuals and Member States are generally barred from invoking violations of these rules before EU courts. The CJEU denied this with a reference to the necessary 'scope for manoeuvre' for the EU institutions in conducting trade negotiations, ${ }^{85}$ and allowed derogations from this rule only in the case of narrowly defined exceptions. ${ }^{86}$

Hence, for all practical purposes, these norms are not to be seen as strict rules which can be either respected or violated. Rather, it is more appropriate to conceive of them as 'optimization requirements' in the sense of Robert Alexy: 'norms that require that something be realised to the greatest extent possible given the legal and factual possibilities' ${ }^{87}$

The slight changes in wording brought about in the Lisbon Treaty regarding trade objectives do not alter this general finding. Pre-Lisbon, the CCP was to 'aim to contribute, in the common interest, to the harmonious development of world trade, the progressive abolition of restrictions on international trade and the lowering of customs barriers' ${ }^{88}$ Under current Article 206 TFEU, the 'Union shall contribute' to these goals. ${ }^{89}$ For one commentator this signifies a shift from 'the aspirational

84 Case 112/80 Dürbeck [1981] ECR 1095, para 44.

85 Case C-149/96 Portugal v Council [1999] ECR I-8395, para 46; and Case C-280/93 Germany v Council [1994] ECR I-0973; see further Antonello Tancredi, 'EC Practice in the WTO: How Wide is the "Scope for Manoeuvre"?' (2004) 15(5) European Journal of International Law 933.

86 Joris Larik, 'Much More Than Trade: The Common Commercial Policy in a Global Context', in Malcolm Evans and Panos Koutrakos (eds), Beyond the Established Legal Orders: Policy Interconnections between the EU and the Rest of the World (Hart 2011) 13-46, 37-40; and Panos Koutrakos, EU International Relations Law (2nd edn, Hart 2015) 301-7.

87 Robert Alexy, A Theory of Constitutional Rights (Oxford University Press 2002) 47. Note also Karl-Peter Sommermann, Staatsziele und Staatszielbestimmungen (Mohr Siebeck 1997) 361 (calling objectives of the state optimization requirements 'par excellence').

88 Art 131(1) TEC (emphasis added).

89 Art 206 TFEU (emphasis added). 
character of the liberalization objective' to one of a 'mandatory nature' 90 However, this in itself would not make trade liberalization a more 'binding' goal than the other external relations objectives of the Union, including its global governance agenda. The language employed with regard to these objectives is essentially the same. ${ }^{91}$

Moreover, the various cross-references between the general external action objectives and the policy-specific objectives, as well as the principle of coherence, militate against any strict hierarchies among objectives. According to Article 21(3) TEU, '[t]he Union shall respect the principles and pursue the objectives' that inspire its external action in all its external policies as well as in the 'external aspects of its other policies'. The CCP, as the Treaties clearly state, 'shall be conducted in the context of the principles and objectives of the Union's external action' (Article 207(1) TFEU). In addition, the weak binding force of such objectives makes discussion about any strict hierarchies between them a rather idle exercise. In view of the various evocations of the principle of 'coherence' and 'consistency' between different policies, ${ }^{92}$ all of the EU's external objectives have to be pursued as an ensemble, geared towards its overall vision of 'good global governance'.

\subsection{Institutional Architecture: Legal Basis and Exclusivity}

While there are various examples of EU measures which harness trade policy for 'good global governance', a central question is which institution is responsible, and of which prerogatives it can avail itself. Here, the constitutional moorings of 'good global governance' play an important role, with their most palpable legal effect being a lens for constitutional interpretation. ${ }^{93}$

This has two related institutional implications regarding the use of trade policy for the benefit of 'good global governance'. First, in the

90 Dimopoulos (n 12) 160.

91 Cf Art 3(5) TEU: '[The EU] shall contribute to peace, security, the sustainable development of the Earth [...]' (emphasis added); Art 208(1), 2nd subpara TFEU: 'Union development cooperation policy shall have as its primary objective the reduction and, in the long term, the eradication of poverty' (emphasis added).

92 Art 16(6), 3rd subpara TEU; Art 21(3), 2nd subpara TEU; Art 7 TFEU.

93 Larik (n 62) 82-5; generally for EU objectives, Koen Lenaerts and Piet Van Nuffel, European Union Law (2nd edn, Sweet \& Maxwell 2011) 111; and Christian Calliess, 'Kollektive Ziele und Prinzipien im Verfassungsrecht der EU - Bestandsaufnahme, Wirkungen und Perspektiven' (2003) 92 Archiv für Rechtsund Sozialphilosophie-Beihefte 85, 92. 
horizontal relationship, concerning the determination of the correct legal basis and the applicable institutional procedures; second, in the vertical dimension, regarding the scope of permissible action of the Member States on the international stage, and also in terms of the pursuit of their own respective visions of 'good global governance'. ${ }^{94}$

These aspects are of particular importance regarding the $\mathrm{CCP}$, the scope and nature of which as a matter of competence have seen drastic changes in the course of time. ${ }^{95}$ Moreover, as the EU legal order has matured over the decades - coupled with the introduction of more policies and competences, as well as value statements and fundamental rights catalogues - Union competences and objectives have parted ways and exist now as two distinct norm categories in EU constitutional law. ${ }^{96}$ However, through interpretation, the latter is still capable of shaping the outer limits of the former.

The CCP, being rather narrowly defined in the beginning and intimately connected with the fledgling Common Market, kindled the idea of an a priori exclusive external EU competence in the case law of the CJEU, which, in the words of the Court, was 'incompatible with the freedom to which the Member States could lay claim by invoking a concurrent power'. ${ }^{97}$ Nevertheless, for want of other suitable legal bases for external action in the Treaties, the Court accepted trade policy to be used also for development cooperation and humanitarian aid, ${ }^{98}$ until those became endowed with their proper legal bases through subsequent treaty reform. This codification of additional policies with their own legal bases and procedures 'had a significant impact on the use of the CCP for

94 The two dimensions are intricately linked in the institutional set-up of the EU, as "the "vertical" interests of the Member States will be felt horizontally through the Council': Bart Van Vooren, EU External Relations Law and the European Neighbourhood Policy: A Paradigm for Coherence (Routledge 2012) 71.

95 Piet Eeckhout, EU External Relations Law (2nd edn, Oxford University Press 2011) 11-69.

96 Joris Larik, 'From Speciality to a Constitutional Sense of Purpose: On the Changing Role of the Objectives of the European Union' (2014) 63 International \& Comparative Law Quarterly 935.

97 Opinion 1/75 [1975] ECR 1355.

98 Case C-54/86 Commission v Council (GSP) [1987] ECR I-1493; also Dimopoulos (n 12) 157-8; and Panos Koutrakos, 'Legal Basis and Delimitation of Competence in EU External Relations', in Marise Cremona and Bruno de Witte (eds), EU Foreign Relations Law: Constitutional Fundamentals (Hart 2008) 171-98. 
pursuing non-trade objectives' ${ }^{99}$ So did the changing scope of the CCP itself, as it represented a moving target in the course of time in terms of using it as a legal basis. Because of the widening of the trade agenda in view of the founding of the WTO in 1995, the CCP came to be considered a partly shared competence. ${ }^{100}$

The pre-Lisbon era hence saw a number of high-profile cases in which different EU institutions fought over whether or not a certain measure or action fell within the scope of the CCP. Typically, the Commission, as the institution with a more powerful position in CCP matters than in other policy areas of a shared character (such as environmental protection), would argue for a legal basis in the CCP, while the Council would argue for the proper legal basis being outside the CCP.101

After Lisbon, the CCP is again entirely exclusive, ${ }^{102}$ and covers a wider field than ever before. It now includes trade in services (including of the cultural and audio-visual kind), commercial aspects of intellectual property, as well as foreign direct investment. ${ }^{103}$ Being now both entirely exclusive in nature and broader than ever before in scope, using the post-Lisbon CCP as a vehicle for promoting 'good global governance' has important legal consequences. According to the TFEU, in such areas 'only the Union may legislate and adopt legally binding acts, the Member States being able to do so themselves only if so empowered by the Union or for the implementation of Union acts' (Article 2(1) TFEU). Moreover, the Commission would be the obvious 'Union negotiator' for international trade agreements (Article 218(3) TFEU), while the Member States would be barred from acting on their own behalf internationally in this area.

99 Dimopoulos (n 12) 157.

100 Opinion 1/94 [1995] ECR I-05267; and later Opinion 1/08 [2009] ECR I-11129; see also Christoph Herrmann, 'Common Commercial Policy after Nice: Sisyphus would have done a Better Job' (2002) 39 Common Market Law Review 7.

101 See Case C-281/01 Commission v Council (Energy Star Agreement) [2002] I-12049; Case C-94/03 Commission v Council (Rotterdam Convention) [2006] ECR I-1; Case C-178/03 Commission v Parliament and Council [2006] ECR I-107; and Case C-411/06 Commission v Parliament and Council (Waste shipments) [2009] ECR I-7585.

102 Art 3(1)(e) TFEU. Note, however, the caveat concerning the area of transport in Art 207(5) TFEU.

103 Art 207 TFEU. While the exact delimitation of trade in services, commercial aspects of intellectual property and foreign direct investment may be difficult, they would seem to match the scope of the relevant WTO agreements: Eeckhout (n 95) 59. 
In this respect, there exists an inherent tension in the idea of a 'global' or 'comprehensive approach', ${ }^{104}$ which advances a broader normative agenda, and the 'constitutional' 105 requirement to identify the proper legal basis, which is an expression of the principle of conferred powers in the EU. ${ }^{106}$ The TEU makes it abundantly clear, however desirable the objectives pursued may be, that the EU shall pursue them 'by appropriate means commensurate with the competences which are conferred upon it in the Treaties' ${ }^{107}$ In this context, regardless of any overarching normative 'vision', policy-specific goals become a key tool that can be utilized in determining within which area of EU policy a particular measure, in view of its aim and content, fits best. ${ }^{108}$

While today the CFSP is deprived of specific objectives in the Treaties, which have to be ascertained instead through judicial interpretation, ${ }^{109}$ the CCP can rely on the objectives of Article 206 TFEU to this end. However, this does not mean that as soon as a non-trade related 'global governance' goal enters the picture, the CCP cannot be used as the sole legal basis of a measure.

In the emerging post-Lisbon case law, promoting a wide notion of 'global governance' - for instance, by exporting certain rules and standards beyond the borders of the EU through the CCP - has received judicial endorsement. In 2013, the CJEU interpreted the reference in Article 207(1) TFEU to the general EU external action objectives in the following manner:

[I]t follows from Article 207(1) TFEU - and, in particular, from the second sentence of that provision, in the words of which the common commercial policy belongs within the context of 'the Union's external action' - that the common commercial policy relates to trade with non-member countries, not to trade in the internal market. ${ }^{110}$

104 From the vantage point of international crisis management, see European Commission and the High Representative of the European Union for Foreign Affairs and Security Policy, 'The EU's Comprehensive Approach to External Conflict and Crises', JOIN(2013), 30 final Brussels, 11 December 2013.

105 Opinion 2/00 (Cartagena Protocol) [2001] ECR I-09713, para 5.

106 Art 5(1) and (2) TEU.

107 Art 3(6) TEU.

108 Dimopoulos (n 12) 166.

109 See Case C-130/10 Parliament v Council, EU:C:2012:472, para 62; and Case C-220/14 P, Ahmed Abdelaziz Ezz, EU:C:2015:147, para 46.

110 Case C-137/12 Commission v Council (European Convention on the legal protection of services based on, or consisting of, conditional access), 
Hence, it was used here as a way to distinguish the CCP from the Internal Market. In this case this was a response to the Council, which had used Article 114 TFEU on the approximation of laws (together with Article 218(5) TFEU) as the legal basis for concluding an international agreement, rather than the CCP with Article 207(4) TFEU. The further reasoning of the Court reveals a wide understanding of the $\mathrm{CCP}$, which is well able to capture a wider agenda of 'global governance': 'An EU act falls within that policy if it relates specifically to international trade in that it is essentially intended to promote, facilitate or govern trade and has direct and immediate effects on trade.' 111

The CJEU noted further that the signing of the international agreement at issue in the case 'on behalf of the European Union, which the contested decision is intended to authorise, is undertaken with a view to encouraging broader ratification of the Convention by Member States of the Council of Europe'. ${ }^{112}$ Hence, the goal was to extend EU regulation 'beyond the borders of the European Union'. ${ }^{113}$ The Court stressed that this goal, "which can be seen [...] to be the primary objective of that decision, therefore has a specific connection with international trade in those services, by dint of which it can legitimately be linked to the common commercial policy'. ${ }^{114}$

This continues the string of case law of the CJEU from before the Lisbon Treaty, according to which trade measures which also contain non-trade components can be comfortably placed on a CCP legal basis. ${ }^{115}$ While this favours the institutional position of the Commission after Lisbon, it also brings the European Parliament to the forefront since, as far as international agreements are concerned, its consent is required now before trade agreements may be concluded by the EU.116 The position of these institutions is thus strengthened, but they are also

EU:C:2013:675, para 56; also Case C-414/11 Daiichi Sankyo and Sanofi Aventis Deutschland, EU:C:2013:520, para 50.

111 Commission v Council (n 110) para 57; Daiichi Sankyo and Sanofi Aventis Deutschland (n 110) para 51.

112 Commission v Council (n 110) para 57.

113 Ibid, para 63.

114 Ibid, para 65.

115 Dimopoulos (n 12) 158-9. However, the trade component must be seen as predominant in such cases. In the case of a twofold trade and non-trade purpose which are both equally important and inextricably linked, a dual legal basis may be necessary; cf Commission v Council (Rotterdam Convention) (n 101). Further, Koutrakos (n 98).

116 Art 207(2) and (3) TFEU together with Art 218(6)(a)(v) TFEU; Eeckhout (n 95) 459. 
called upon to be protagonists in advancing 'good global governance' through trade.

The Council retains important supervisory powers in trade policy under Article 207 TFEU, including through the Trade Policy Committee (formerly known as the 'Article 133 Committee'), preserving its role in promoting the wider normative agenda through the CCP. However, the implications for its constituents, the Member States, are drastic. Given the exclusive nature of the entirety of the CCP, Member States are barred from acting on their own behalf on the international stage. This means also that they can no longer pursue their own visions of 'good global governance', constitutionally codified or otherwise, in the international arena as far as the CCP is concerned: for them in such cases it is henceforth 'good global governance' through the EU and its trade policy. In this sense, EU external action becomes less 'polyphonic'. ${ }^{117}$ In the $\mathrm{CCP}$, the Union speaks with one voice on the international stage, and the message it is constitutionally mandated to spread globally is to be found in Articles 21 and 3(5) TEU.

\subsection{Implementing 'Good Global Governance' through Trade}

Union objectives are to guide the exercise of EU powers, and their pursuit is to resonate through the secondary legislation and other acts of the Union. ${ }^{118}$ This corresponds with a view of coherence as goal-oriented 'complementarity'119 and 'positive synergy'.120 As Bart van Vooren rightly argues, 'coherence thus implies that norms, actors and instruments are positively aligned towards EU Treaty objectives' ${ }^{121}$ Despite the weak legal force and the width of the EU's constitutional mandate to foster good global governance, including through its trade policy, there are a number of examples of trade or trade-related measures through which the EU seeks to implement this overarching vision. Two recent initiatives of

117 Christophe Hillion, 'Mixity and Coherence in EU External Relations: The Significance of the "Duty of Cooperation", in Christophe Hillion and Panos Koutrakos (eds), Mixed Agreements Revisited: The EU and its Member States in the World (Hart 2010) 87-115, 87.

118 Calliess (n 93) 90. See, for example, Geraets and Natens (Chapter 11, this volume).

119 Marise Cremona, 'Coherence in European Union Foreign Relations Law', in Panos Koutrakos (ed), European Foreign Policy: Legal and Political Perspectives (Edward Elgar Publishing 2011) 55-92, 89.

120 Bart Van Vooren (n 94) 69.

121 Ibid 71 (emphasis added). 
the EU can serve to illustrate this: one is squarely a CCP measure; the other is not.

First, the EU's Generalised System of Preferences (GSP), in its revised legal framework, ${ }^{122}$ is arguably the most obvious example. It is formalized as a measure with a CCP legal basis but which clearly pursues a wider agenda. ${ }^{123}$ Regulation (EU) No. 978/2012 is based on Article 207 TFEU (CCP), but its preamble also recalls that ' $[\mathrm{t}]$ he Union's common commercial policy shall be guided by the principles and pursue the objectives set out in the general provisions on the Union's external action, laid down in Article 21 of the Treaty on European Union (TEU)' (second recital). More specifically, the Regulation notes in the fourth recital that

[t]he Union's common commercial policy is to be consistent with and to consolidate the objectives of the Union policy in the field of development cooperation, laid down in Article 208 of the Treaty on the Functioning of the European Union (TFEU), in particular the eradication of poverty and the promotion of sustainable development and good governance in the developing countries.

Among the various ways to obtain preferences through this scheme, the 'special incentive arrangement for sustainable development and good governance' (GSP+) stands out as the prime illustration of harnessing trade policy for the benefit of a wider normative agenda. Under GSP+, developing countries eligible for the general scheme can gain additional preferences on the condition that they ratify a number of conventions listed in an annex and effectively implement them (Article 9(1) of Regulation (EU) No. 978/2012). These include international treaties on human rights, international labour rights, environmental protection and good governance, as listed in Annex VIII of the Regulation. To this end, the respective third countries also submit themselves to being monitored by the European Commission (Article 13). In the event of non-compliance with these conventions, benefits may be withdrawn (Article 15).

However, such measures are not always required to have their legal basis, or 'centre of gravity', in the $\mathrm{CCP}$, but can still harness trade policy to advance the EU's entrenched global normative agenda. An example of

122 Regulation (EU) No. 978/2012 of 25 October 2012 applying a scheme of generalised tariff preferences and repealing Council Regulation (EC) No 732/ 2008 [2012] OJ L 303/1.

123 See further Chapters 8 and 9, this volume by Laura Beke and Nicolas Hachez, and James Yap respectively. 
this is Regulation (EU) No. 995/2010 on timber and timber products, ${ }^{124}$ which, by contrast, is based on Article 192 TFEU - the EU's environmental policy. This is because the rationale of this measure is environmental protection in terms of 'maintaining biodiversity and ecosystem functions and protecting the climate system' (first recital) and a contribution 'to the Union's climate change mitigation efforts' (third recital). The commercial dimension of the Regulation, however, is apparent in the fact that it 'lays down the obligations of operators who place timber and timber products on the internal market for the first time, as well as the obligations of traders' (Article 1). It does so by establishing various duties on operators and traders with a view to ensuring, through tracing and due diligence, that the timber and timber products introduced into the EU market comply with the exporting state's (timber) legislation.

Whatever their legal basis or the institutional and procedural setting, the basic idea behind these and other EU measures is the same: compliance with internationally recognized rules and standards which accord with the EU's vision of 'good global governance' lowers the barriers to accessing the EU internal market. This is one of the EU's most important instruments - if not the most important instrument for leverage which it has at its disposal. In doing so, the EU and its institutions breathe life into the constitutionally entrenched goals of EU external action and respond to the constitutional mandate they entail.

\section{CONCLUSION}

This chapter has sought to elucidate the notion of 'good global governance though trade' as a constitutional matter for the EU. It has done so through a combined historical, comparative and legal-institutional analysis, which yields the following main conclusions. First, from the outset of European integration, both the centrality of the CCP in the external relations of the EU, as well as a wider normative agenda, found expression in the primary law. Over the course of several decades the latter became more clearly articulated, with the Convention on the Future of Europe devising the EU's comprehensive 'mission statement', ${ }^{125}$ now

124 Regulation (EU) No. 995/2010 of 20 October 2010 laying down the obligations of operators who place timber and timber products on the market [2010] OJ L 295/23. See further Chapter 11, this volume by Dylan Geraets and Bregt Natens.

125 Bart Van Vooren, Steven Blockmans and Jan Wouters, 'The Legal Dimension of Global Governance: What Role for the EU?', in Bart Van Vooren, 
to be found in Articles 3(5) and 21 TEU and its explicit link to trade policy through Article 207(1) TFEU.

Second, such an explicit constitutional linkage between trade policy and general contributions to 'good global governance' represents a peculiarity from a comparative perspective. Only few constitutions address trade policy from a substantive point of view. The EU does so for historical reasons, and even after Lisbon the $\mathrm{CCP}$ retains objectives of its own. However, a general constitutional mandate to utilize trade policy to advance this wider global normative agenda is a veritable novelty in constitutional language.

Third, from a legal-institutional point of view, the introduction of Articles 3(5) and 21 TEU makes the pursuit of 'good global governance' along the lines expressed in these provisions an obligation of constitutional rank, which is to guide the exercise of EU powers in its external action. However, the width of these goals and their weak bindingness limit their obligatory and prohibitive force, not least for adjudicatory purposes. Rather, they serve for constitutional interpretation. As the emerging post-Lisbon case law affirms, the CCP - now wider in scope than ever and entirely exclusive - can serve as the legal basis (or at least one of the legal bases) for a broad range of measures which advance a wider agenda. As a consequence, this strengthens not only the institutional position of the Commission in EU external action, but also that of the Parliament as far as international agreements are concerned. The Member States, by contrast, will have to pursue their own ideas of 'good global governance' through the Council as far as matters pertaining to the post-Lisbon CCP are concerned. Regardless of the legal basis and the institutional procedures to be followed, the only way to live up to this constitutional mandate is through specific measures. Post-Lisbon, there is evidence of trade measures that explicitly acknowledge the link with the wider normative agenda of Article 21 TEU, and also of other measures, for instance in the environmental domain, with a clear trade dimension. Both types, their different legal bases notwithstanding, must be considered as steps which harness the EU's commercial clout in the interest of promoting 'good global governance' and the coherence between different policy domains.

In sum, the primary law post-Lisbon is abundantly clear: 'good global governance' through trade not just a (fleeting) policy preference; it is a constitutional duty firmly moored in the Treaties. Consequently, the trade

Steven Blockmans and Jan Wouters (eds), The EU's Role in Global Governance: The Legal Dimension (Oxford University Press 2013). 
policy of the EU is certainly no end in itself, but a powerful means to 'higher ends' 126 now prominently enshrined in the highest laws of the EU.

126 From War to Peace: A European Tale, Nobel Peace Prize Lecture on behalf of the European Union by Herman Van Rompuy, President of the European Council, and José Manuel Durão Barroso, President of the European Commission, Oslo, 10 December 2012, in which then Commission President Barroso noted that European unity 'is not an end in itself, but a means to higher ends'. 